\title{
Single Cell Oil Production with Cutaneotrichosporon curvatus (syn, Cryptococcus curvatus) PY39 and Its Use for Biodiesel Preparation
}

Tamene Milkessa Jiru ( $\sim$ tamene1971@gmail.com )

University of Gondar

Research

Keywords: Biodiesel, Culture conditions, Cutaneotrichosporon curvatus (syn, Cryptococcus curvatus), Fatty acid, Oleaginous yeast

Posted Date: April 1st, 2020

DOI: https://doi.org/10.21203/rs.3.rs-20536/v1

License: (c) (1) This work is licensed under a Creative Commons Attribution 4.0 International License.

Read Full License 


\section{Abstract}

Background: Microorganisms including yeasts that are capable of accumulating lipids above 20 to $70 \%$ of their dry biomass are collectively named oleaginous. The oil produced from such microorganisms can be used as alternative sources of oils for human consumption, feedstocks for production of biodiesel, components in paints, coatings, detergents, cleaning products, cosmetics, plastics, rubber and intermediate products.

Results: In this study Cutaneotrichosporon curvatus (Cryptococcus curvatus) PY39, an oleaginous yeast, isolated from flower surface in Ethiopia, was grown under nitrogen-limited media. The capacity of this strain with respect to biomass production, lipid yield and lipid content was evaluated. To determine the optimal culture conditions for this oleaginous yeast, different carbon and nitrogen sources, carbon to nitrogen $(\mathrm{C} / \mathrm{N})$ ratio, $\mathrm{pH}$, incubation temperature, shaking speed and incubation period were investigated. The optimal fermentation conditions were obtained as follows: $70 \mathrm{~g} / \mathrm{L}$ of glucose as carbon source; combinations of ammonium sulphate and yeast extract as nitrogen sources at, respectively, $0.50 \mathrm{~g} / \mathrm{L}$ and $0.47 \mathrm{~g} / \mathrm{L}$; initial $\mathrm{pH}$ of 5.0 ; temperature at $30^{\circ} \mathrm{C}$, shaking speed of $225 \mathrm{rpm}$, and cultivated for $144 \mathrm{~h}$. Under the optimized conditions, C.curvatus PY39 accumulated lipids up to $7.22 \pm 0.26 \mathrm{~g} / \mathrm{L}$ on dry biomass basis. Such values correspond to lipid content of $48.66 \pm 0.60 \%$. This strain was further grown on media containing peel mixtures of papaya and mango. Under the optimized conditions, C. curvatus PY39 exhibited a lipid yield and lipid content of $3.95 \pm 0.67 \mathrm{~g} / \mathrm{L}$ and $35.02 \pm 1.63 \%$, respectively. The fatty acid profiles were analyzed using gas chromatography. Data revealed the presence of significant amount of oleic acid $(54.40 \pm 1.15 \%)$, palmitic acid $(17.39 \pm 0.47 \%)$, stearic acid $(13.16 \pm 0.93 \%)$ and low amount of other fatty acids in the extracted yeast oils which indicate that the fatty acid profiles were very similar to that of conventional vegetable oils.

Conclusion: The results of fatty acid profiles showed that the microbial lipids from the studied yeast can be good feedstocks for biodiesel production.

\section{Background}

Microorganisms capable of accumulating lipids above 20 to $70 \%$ of their dry biomass are collectively named oleaginous [1]. The oil produced can be exploited as alternative sources of oils and fats for human consumption and, increasingly, for renewable energy (biodiesel) production [2] and components in paints and coatings, detergents, cleaning products, cosmetics, plastics, rubber, crop protection and intermediate products or synthons[3].

Oil accumulation by oleaginous microorganisms depends on the culture conditions such as optimization of carbon and nitrogen sources, $\mathrm{C} / \mathrm{N}$ ratio, incubation period and temperature, $\mathrm{pH}$, agitation and aeration rate $[4,5]$. Optimizations of culture conditions are critical for increased biomass yield and lipid production by oleaginous microorganisms. Moreover, the data generated is useful for scale up efforts aimed at biodiesel production. 
Optimization of cultivation parameters can result in higher lipid production by oleaginous yeasts and fosters their potential for industrial application. Optimization is an essential step of each industrial process because it can result in higher production and reduced cost of production [6].

Oleaginous microorganisms convert the carbon sources contained in various substrates into storage lipid under suitable culture conditions [7]. In order to reduce the cost of microbial oil production, low-cost raw materials like lignocellulosic hydrolysates such rice straw [9] and rice hull [7], glycerol [9, 10], sugar industry by-product such as molasses [11, 12, 13], effluent from steam of fish processing [14], whey [15], beer factory wastewater [16], starch wastewater [17], and products of fruit processing industry [18, 19] were investigated.

Papaya and mango are produced in vast amount worldwide. Various juice producing industries and local juice sellers produce a huge amount of different fruit wastes including fruit peels. The peels from these fruits are disposed as wastes. The utilization of such wastes is needed to be emphasized to save the resources and protect the environment from pollution [18]. Fruit waste has high level of sugars, including sucrose, glucose and fructose [20]. These fruit wastes are suitable for the production of SCO [18, 19], ethanol, biogas, lactic acid, enzymes and single cell protein [21]. Banana peel can also be used for the production of wine [22]. To improve the economic competitiveness of the bioprocess microbial oil (TAGs), the use of wastes that have low or even negative value can be used as natural substrates [23,24]. These microbial oils can be used as feedstocks for the production of biodiesel [2].

This study aimed to investigate the effect of different cultivation factors on biomass production, lipid yield and lipid content of C. curvatus PY39. In addition, the potential of lipid production capacity of such selected oleaginous yeast was evaluated by cultivating it on mixtures of papaya and mango peels. Furthermore, the fatty acid profiles of this yeast were analyzed using gas chromatography.

\section{Results}

\section{Effect of various parameters on biomass production and lipid yield}

In the present study, the effects of various carbon sources (glucose, sucrose, maltose, lactose, galactose, xylose and glycerol) on biomass yield and lipid content by C. curvatus PY39 was tested using nitrogenlimited media. Maximum biomass $(14.53 \pm 0.41 \mathrm{~g} / \mathrm{L})$ and lipid content $(48.66 \pm 0.60 \%)$ were attained by C. curvatus PY39 when glucose was supplied as a sole source of carbon (Table 1). On the other hand, C. curvatus PY39 gave the minimum lipid yield of $8.38 \pm 0.26 \mathrm{~g} / \mathrm{L}$ and lipid content of $24.70 \pm 0.48 \%$ when grown in nitrogen-limited medium containing xylose. 
Table 1

Effect of medium components on cell growth and lipid accumulation of C. curvatus PY39

\begin{tabular}{llll} 
Parameter & Biomass $(\mathrm{g} / \mathrm{L})$ & Lipid yield $(\mathrm{g} / \mathrm{L})$ & Lipid content \\
\hline Carbon source & & & \\
Glucose & $14.53 \pm 0.41^{\mathrm{a}}$ & $7.07 \pm 0.27^{\mathrm{a}}$ & $48.66 \pm 0.60^{\mathrm{a}}$ \\
\hline Sucrose & $12.75 \pm 0.46^{\mathrm{b}}$ & $4.70 \pm 0.06^{\mathrm{b}}$ & $36.87 \pm 0.66^{\mathrm{c}}$ \\
\hline Maltose & $11.67 \pm 0.41^{\mathrm{c}}$ & $4.66 \pm 0.06^{\mathrm{b}}$ & $39.93 \pm 1.36^{\mathrm{b}}$ \\
\hline Galactose & $11.78 \pm 0.99^{\mathrm{c}}$ & $3.76 \pm 0.22^{\mathrm{c}}$ & $32.26 \pm 0.89^{\mathrm{e}}$ \\
\hline Xylose & $8.38 \pm 0.26^{\mathrm{d}}$ & $2.07 \pm 0.23^{\mathrm{d}}$ & $24.70 \pm 0.48^{\mathrm{d}}$ \\
\hline Glycerol & $11.21 \pm 0.89^{\mathrm{c}}$ & $4.12 \pm 0.65^{\mathrm{c}}$ & $36.76 \pm 1.43^{\mathrm{c}}$
\end{tabular}

Glucose concentration ( $\mathrm{g} / \mathrm{L})$

\begin{tabular}{|llll|}
\hline 10 & $11.88 \pm 1.10^{\mathrm{b}}$ & $3.42 \pm 0.54^{\mathrm{c}}$ & $28.81 \pm 2.2^{\mathrm{d}}$ \\
\hline 30 & $13.40 \pm 0.42^{\mathrm{b}}$ & $4.66 \pm 0.63^{\mathrm{bc}}$ & $34.78 \pm 2.64^{\mathrm{b}}$ \\
\hline 50 & $14.35 \pm 1.08^{\mathrm{ab}}$ & $4.38 \pm 0.66^{\mathrm{bc}}$ & $30.52 \pm 1.59^{\mathrm{c}}$ \\
\hline 90 & $16.82 \pm 2.27^{\mathrm{a}}$ & $6.80 \pm 0.75^{\mathrm{a}}$ & $40.43 \pm 1.73^{\mathrm{a}}$ \\
\hline $\mathrm{Nitrogen}$ source & $15.04 \pm 0.75^{\mathrm{ab}}$ & $5.39 \pm 0.61^{\mathrm{ab}}$ & $35.84 \pm 1.56^{\mathrm{b}}$ \\
\hline$\left(\mathrm{NH}_{4}\right)_{2} \mathrm{SO}_{4}, \mathrm{YE}$ & & & \\
\hline $\mathrm{NH}_{4} \mathrm{Cl}$, peptone & $15.75 \pm 0.25^{\mathrm{b}}$ & $6.35 \pm 0.22^{\mathrm{a}}$ & $40.31 \pm 0.79^{\mathrm{a}}$ \\
\hline $\mathrm{NH}_{4} \mathrm{Cl}, \mathrm{YE}$ & $16.89 \pm 0.23^{\mathrm{a}}$ & $6.21 \pm 0.26^{\mathrm{ab}}$ & $36.76 \pm 0.36^{\mathrm{b}}$ \\
\hline$\left(\mathrm{NH}_{4}\right)_{2} \mathrm{SO}_{4}$, peptone & $16.91 \pm 0.40^{\mathrm{a}}$ & $6.10 \pm 0.08^{\mathrm{ab}}$ & $36.01 \pm 0.26^{\mathrm{b}}$ \\
\hline $\left.\mathrm{NH}_{4}\right)_{2} \mathrm{SO}_{4}$, urea & $16.25 \pm 0.12^{\mathrm{b}}$ & $6.15 \pm 0.05^{\mathrm{ab}}$ & $37.84 \pm 0.41^{\mathrm{b}}$ \\
\hline $\mathrm{NH}_{4} \mathrm{Cl}$, urea & $15.10 \pm 0.15^{\mathrm{c}}$ & $5.39 \pm 0.11^{\mathrm{b}}$ & $35.70 \pm 0.19^{\mathrm{c}}$ \\
\hline
\end{tabular}

All parameters are expressed as mean $\pm S D$ values in the same column, $n=3$, within each column, means

are significantly different $(p<0.05)$, unless they have a common letter.

YE- Yeast Extract 


\begin{tabular}{|lccc|}
\hline Parameter & Biomass $(\mathbf{g} / \mathrm{L})$ & Lipid yield $(\mathbf{g} / \mathrm{L})$ & Lipid content $(\%)$ \\
\hline C/N ratio & & & \\
\hline 40 & $10.24 \pm 1.13^{\mathrm{d}}$ & $2.22 \pm 0.29^{\mathrm{d}}$ & $21.67 \pm 1.8^{\mathrm{f}}$ \\
\hline 60 & $10.75 \pm 1.06^{\mathrm{d}}$ & $2.54 \pm 0.34^{\mathrm{d}}$ & $23.62 \pm 0.88^{\mathrm{e}}$ \\
\hline 80 & $10.79 \pm 0.54^{\mathrm{d}}$ & $3.52 \pm 0.19^{\mathrm{c}}$ & $32.61 \pm 1.48^{\mathrm{d}}$ \\
\hline 100 & $11.55 \pm 1.29^{\mathrm{c}}$ & $4.49 \pm 0.61^{\mathrm{b}}$ & $38.86 \pm 1.77^{\mathrm{c}}$ \\
\hline 120 & $12.68 \pm 1.23^{\mathrm{b}}$ & $5.12 \pm 0.52^{\mathrm{b}}$ & $40.37 \pm 0.56^{\mathrm{b}}$ \\
\hline 140 & $13.97 \pm 0.90^{\mathrm{a}}$ & $5.83 \pm 0.33^{\mathrm{a}}$ & $41.79 \pm 2.31^{\mathrm{a}}$ \\
\hline 160 & $12.12 \pm 0.66^{\mathrm{b}}$ & $4.89 \pm 0.45^{\mathrm{b}}$ & $40.85 \pm 2.94^{\mathrm{b}}$ \\
\hline $\begin{array}{l}\text { All parameters are expressed as mean } \pm \text { SD values in the same column, } \mathrm{n}=3, \text { within each column, } \\
\text { means }\end{array}$ & & \\
\hline are significantly different $(\mathrm{p}<0.05)$, unless they have a common letter. & \\
\hline YE- Yeast Extract & & \\
\hline
\end{tabular}

To know the optimum glucose concentration for maximum lipid content per dry biomass of $\mathrm{C}$. curvatus PY39, various concentrations, i.e., 10, 30, 50, 70 and $90 \mathrm{~g} / \mathrm{L}$ glucose concentrations were carried out. Results indicate that the optimum glucose concentration that led to maximum biomass and lipid content was $70 \mathrm{~g} / \mathrm{L}$ leading to a biomass production of $16.82 \pm 2.27 \mathrm{~g} / \mathrm{L}$ and lipid content of $40.43 \pm 1.73 \%$ (Table 1). On the other hand, the least amount of biomass and lipid content were attained by $\mathrm{C}$. curvatus PY39, when the media contained $10 \mathrm{~g} / \mathrm{L}$ glucose (Table 1). The lowest biomass and lipid contents were exhibited by C. curvatus PY39 in a nitrogen-limited medium with $10 \mathrm{~g} / \mathrm{L}$ glucose viz., $11.88 \pm 1.10 \mathrm{~g} / \mathrm{L}$ and $28.81 \pm 2.02 \%$, respectively. As shown on Table $1,70 \mathrm{~g} / \mathrm{L}$ glucose was the most favorable concentration for maximum lipid production by C. curvatus PY39 and hence was selected for further activities.

The effect of combined organic nitrogen (yeast extract, peptone and urea at $0.30 \mathrm{~g} / \mathrm{L}$ concentration) and inorganic nitrogen sources $\left(\mathrm{NH}_{4}\right)_{2} \mathrm{SO}_{4}$ and $\mathrm{NH}_{4} \mathrm{Cl}$ at $0.30 \mathrm{~g} / \mathrm{L}$ concentration by C.curvatus PY39, were determined in the nitrogen-limited media containing optimized glucose concentrations for each oleaginous yeast. As shown in Table 1, C.curvatus PY39 gave maximum biomass when it was grown on medium containing $\mathrm{NH}_{4} \mathrm{Cl}$ and peptone in combinations as well as in the medium containing $\mathrm{NH}_{4} \mathrm{Cl}$ and yeast extract. The biomass exhibited by $\mathrm{C}$. curvatus $\mathrm{PY} 39$ when grown on a medium containing $\mathrm{NH}_{4} \mathrm{Cl}$ and peptone was $16.89 \pm 0.23 \mathrm{~g} / \mathrm{L}$, while a biomass of $16.91 \pm 0.40 \mathrm{~g} / \mathrm{L}$ was attained by this yeast when grown on medium containing $\mathrm{NH}_{4} \mathrm{Cl}$ and peptone. This yeast gave maximum lipid content (40.31 \pm $0.79 \%)$ when $\left(\mathrm{NH}_{4}\right)_{2} \mathrm{SO}_{4}$ and yeast extract were used in combinations as nitrogen sources. 
Results also showed that the combined nitrogen sources that gave lowest biomass and lipid content were $\mathrm{NH}_{4} \mathrm{Cl}$ and urea (Table 1) for C.curvatus PY39, leading to biomass and lipid contents of $14.96 \pm 1.21 \mathrm{~g} / \mathrm{L}$ and $34.63 \pm 0.56 \%$, respectively.

Based on the results in Table 1, the lipid content at different combinations of different nitrogen sources, one can understand that $\left(\mathrm{NH}_{4}\right)_{2} \mathrm{SO}_{4}$ and yeast extract are the optimum nitrogen sources for $\mathrm{C}$. curvatus PY39. Accordingly, $\left(\mathrm{NH}_{4}\right)_{2} \mathrm{SO}_{4}$ and yeast extract were selected as optimal nitrogen sources for the yeast C. curvatus PY39 for further investigations.

The effect of $\mathrm{C} / \mathrm{N}$ ratio on biomass production and lipid content of $\mathrm{C}$. curvatus PY39 were studied by varying $\mathrm{C} / \mathrm{N}$ ratios from 40 to 160 in nitrogen-limited media composed of $70 \mathrm{~g} / \mathrm{L}$ of glucose, $0.5 \mathrm{~g} / \mathrm{L}$ of yeast extract and various concentrations of $\left(\mathrm{NH}_{4}\right)_{2} \mathrm{SO}_{4}$ as shown in Table 2 and adjusted pH of 5.5. To know the total nitrogen content of yeast extract, Kjeldahl method was used and the approximate result obtained was $20 \%$.

Table 2

The $\mathrm{C} / \mathrm{N}$ ratio in nitrogen-limited medium

\begin{tabular}{|lll|}
\hline C/N ratio & Carbon source (glucose) & Nitrogen sources \\
\hline 40 & $70 \mathrm{~g} / \mathrm{L}$ & $0.5 \mathrm{~g} / \mathrm{L}$ yeast extract and $2.83 \mathrm{~g} / \mathrm{L}\left(\mathrm{NH}_{4}\right)_{2} \mathrm{SO}_{4}$ \\
\hline 60 & $70 \mathrm{~g} / \mathrm{L}$ & $0.5 \mathrm{~g} / \mathrm{L}$ yeast extract and $1.74 \mathrm{~g} / \mathrm{L}\left(\mathrm{NH}_{4}\right)_{2} \mathrm{SO}_{4}$ \\
\hline 80 & $70 \mathrm{~g} / \mathrm{L}$ & $0.5 \mathrm{~g} / \mathrm{L}$ yeast extract and $1.18 \mathrm{~g} / \mathrm{L}\left(\mathrm{NH}_{4}\right)_{2} \mathrm{SO}_{4}$ \\
\hline 100 & $70 \mathrm{~g} / \mathrm{L}$ & $0.5 \mathrm{~g} / \mathrm{L}$ yeast extract and $0.85 \mathrm{~g} / \mathrm{L}\left(\mathrm{NH}_{4}\right)_{2} \mathrm{SO}_{4}$ \\
\hline 120 & $70 \mathrm{~g} / \mathrm{L}$ & $0.5 \mathrm{~g} / \mathrm{L}$ yeast extract and $0.61 \mathrm{~g} / \mathrm{L}\left(\mathrm{NH}_{4}\right)_{2} \mathrm{SO}_{4}$ \\
\hline 140 & $70 \mathrm{~g} / \mathrm{L}$ & $0.5 \mathrm{~g} / \mathrm{L}$ yeast extract and $0.47 \mathrm{~g} / \mathrm{L}\left(\mathrm{NH}_{4}\right)_{2} \mathrm{SO}_{4}$ \\
\hline 160 & $70 \mathrm{~g} / \mathrm{L}$ & $0.5 \mathrm{~g} / \mathrm{L}$ yeast extract and $0.35 \mathrm{~g} / \mathrm{L}\left(\mathrm{NH}_{4}\right)_{2} \mathrm{SO}_{4}$ \\
\hline
\end{tabular}

The results of the effect of $\mathrm{C} / \mathrm{N}$ ratio on biomass, lipid yield and lipid content by C.curvatus PY39 yeasts is also presented in Table 1. At C/N ratio of 140, C.curvatus PY39 exhibited its maximum lipid yield and lipid contents, i.e., $6.20 \pm 0.33 \mathrm{~g} / \mathrm{L}$ and $41.75 \pm 2.31 \%$, respectively per dry biomass of $14.85 \pm 0.90 \mathrm{~g} / \mathrm{L}$. On the contrary, the least biomass, lipid yield and lipid content was exhibited by C. curvatus PY39 in a nitrogen-limited media with $\mathrm{C} / \mathrm{N}$ ratio of $40 \mathrm{viz} ., 10.24 \pm 1.13 \mathrm{~g} / \mathrm{L}, 2.22 \pm 0.29 \mathrm{~g} / \mathrm{L}$ and $21.67 \pm 1.80 \%$, respectively. Based on the above result, $\mathrm{C} / \mathrm{N}$ ratio of 140 was the optimum and selected value for C.curvatus PY39 and hence was used for further studies.

To know the best initial pH for maximum production of cell biomass and cellular lipid content in C.curvatus PY39, a nitrogen-limited medium with $\mathrm{pH}$ ranging from 4.0 to 7.0 were tested. Optimum pH 
that led to maximum biomasses production were $5.0(16.71 \pm 0.11 \mathrm{~g} / \mathrm{L})$ and $5.5(16.32 \pm 0.14 \mathrm{~g} / \mathrm{L})$.

Results indicate that the optimum $\mathrm{pH}$ that leads to maximum lipid yield and lipid content was 5.0. Results indicate that the optimum $\mathrm{pH}$ that led to maximum lipid yield and lipid content was 5.0 leading to lipid yield of $7.05 \pm 0.14 \mathrm{~g} / \mathrm{L}$ and lipid content of $42.19 \pm 0.50 \%$ (Table 3). Results also showed that the pH that leads to the lowest biomass and lipid content was 7.0 for C. curvatus PY39, leading to biomass and lipid contents of $12.15 \pm 0.05 \mathrm{~g} / \mathrm{L}$ and $27.98 \pm 2.23 \%$ (Table 3 ). The lipid yield and cellular lipid percentage content the dry biomass at different initial $\mathrm{pH}$ values gave a clear picture for the optimum $\mathrm{pH}$ values for this oleaginous yeast strain. Accordingly, pH 5.0 was selected as the optimum pH in the medium for $\mathrm{C}$. curvatus PY39.

Table 3 Effect of temperature, initial pH, agitation speed and incubation period on cell growth and lipid accumulation of C. curvatus PY39 


\begin{tabular}{|l|l|l|l|}
\hline Cultivation conditions & Biomass $(\mathrm{g} / \mathrm{L})$ & Lipid yield $(\mathrm{g} / \mathrm{L})$ & Lipid content (\%) \\
\hline $\mathrm{pH}$ & & & \\
\hline 4.0 & $13.30 \pm 0.28 \mathrm{c}$ & $3.95 \pm 0.25 \mathrm{~d}$ & $29.70 \pm 1.14 \mathrm{e}$ \\
\hline 4.5 & $14.48 \pm 0.34 \mathrm{~b}$ & $5.45 \pm 0.25 \mathrm{c}$ & $37.65 \pm 1.54 \mathrm{c}$ \\
\hline 5.0 & $16.71 \pm 0.11 \mathrm{a}$ & $7.05 \pm 0.14 \mathrm{a}$ & $42.19 \pm 0.50 \mathrm{a}$ \\
\hline 5.5 & $16.32 \pm 0.14 \mathrm{ab}$ & $6.64 \pm 0.05 \mathrm{~b}$ & $40.67 \pm 0.27 \mathrm{~b}$ \\
\hline 6.0 & $14.97 \pm 0.07 \mathrm{~b}$ & $5.65 \pm 0.01 \mathrm{c}$ & $37.82 \pm 1.05 \mathrm{c}$ \\
\hline 6.5 & $14.94 \pm 0.37 \mathrm{~b}$ & $4.82 \pm 0.65 \mathrm{~cd}$ & $32.26 \pm 0.60 \mathrm{~d}$ \\
\hline 7.0 & $12.15 \pm 0.05 \mathrm{e}$ & $3.39 \pm 0.16 \mathrm{e}$ & $27.98 \pm 2.23 \mathrm{f}$ \\
\hline Temperature (oC) & & & \\
\hline 20 & $12.87 \pm 0.64 \mathrm{a}$ & $3.89 \pm 0.34 \mathrm{c}$ & $30.22 \pm 1.02 \mathrm{~d}$ \\
\hline 25 & $13.05 \pm 0.37 \mathrm{a}$ & $4.61 \pm 0.42 \mathrm{~b}$ & $35.32 \pm 0.73 \mathrm{~b}$ \\
\hline 30 & $14.97 \pm 0.03 \mathrm{a}$ & $6.67 \pm 0.48 \mathrm{a}$ & $45.49 \pm 0.67 \mathrm{a}$ \\
\hline 35 & $11.66 \pm 0.62 \mathrm{~b}$ & $3.77 \pm 0.18 \mathrm{c}$ & $32.33 \pm 0.34 \mathrm{c}$ \\
\hline 40 & $8.17 \pm 0.13 \mathrm{c}$ & $1.92 \pm 0.17 \mathrm{~d}$ & $23.52 \pm 0.36 \mathrm{e}$ \\
\hline Agitation speed (rpm) & & & \\
\hline 100 & $11.44 \pm 0.41 \mathrm{c}$ & $3.31 \pm 0.25 \mathrm{~d}$ & $28.93 \pm 0.77 \mathrm{f}$ \\
\hline 125 & $12.49 \pm 1.17 \mathrm{~b}$ & $4.39 \pm 0.16 \mathrm{c}$ & $35.16 \pm 1.36 \mathrm{e}$ \\
\hline 150 & $12.58 \pm 0.35 \mathrm{~b}$ & $4.98 \pm 0.57 \mathrm{c}$ & $39.58 \pm 2.44 \mathrm{~d}$ \\
\hline 175 & $12.75 \pm 1.27 \mathrm{~b}$ & $5.12 \pm 0.42 \mathrm{c}$ & $40.18 \pm 0.86 \mathrm{c}$ \\
\hline 200 & $12.98 \pm 0.36 \mathrm{~b}$ & $6.33 \pm 0.19 \mathrm{~b}$ & $48.77 \pm 0.44 \mathrm{~b}$ \\
\hline 225 & $13.75 \pm 0.77 \mathrm{a}$ & $6.93 \pm 0.66 \mathrm{a}$ & $50.41 \pm 2.36 \mathrm{a}$ \\
\hline Incubation period (h) & & & \\
\hline 0 & $1.25 \pm 0.45 \mathrm{f}$ & $0.66 \pm 0.02 \mathrm{f}$ & $5.28 \pm 0.51 \mathrm{~h}$ \\
\hline 24 & $9.26 \pm 1.24 \mathrm{e}$ & $2.04 \pm 0.15 \mathrm{e}$ & $22.03 \pm 0.58 \mathrm{~g}$ \\
\hline 48 & $11.75 \pm 0.69 \mathrm{~d}$ & $3.26 \pm 0.53 \mathrm{~d}$ & $27.74 \pm 0.65 \mathrm{f}$ \\
\hline 72 & $12.98 \pm 0.53 \mathrm{c}$ & $4.35 \pm 0.24 \mathrm{c}$ & $33.51 \pm 1.39 \mathrm{e}$ \\
\hline 96 & $13.78 \pm 1.01 \mathrm{~b}$ & $5.26 \pm 0.63 \mathrm{~b}$ & $38.23 \pm 2.64 \mathrm{c}$ \\
\hline 120 & $15.75 \pm 0.86 \mathrm{a}$ & $7.22 \pm 0.26 \mathrm{a}$ & $45.88 \pm 0.50 \mathrm{a}$ \\
\hline 144 & $13.75 \pm 0.56 \mathrm{~b}$ & $5.60 \pm 0.14 \mathrm{~b}$ & $40.75 \pm 1.50 \mathrm{~b}$ \\
\hline 168 & $12.68 \pm 1.55 \mathrm{c}$ & $4.60 \pm 0.29 \mathrm{c}$ & $36.28 \pm 2.72 \mathrm{~d}$ \\
\hline
\end{tabular}

All parameters are expressed as mean \pm SD values in the same column, $n=3$, within each column, means are significantly different $(\mathrm{p}<0.05)$, unless they have a common letter.

Biomass and cellular lipid content of oleaginous yeast, namely C. curvatus PY39 was tested by growing each at temperatures of $20,25,30,35$ and $40^{\circ} \mathrm{C}$ in a nitrogen-limited culture media. As it is presented in Table 3, the best temperature for maximum biomass yield was $30^{\circ} \mathrm{C}$ for C.curvatus PY39 that led to biomass production of $14.97 \pm 0.03 \mathrm{~g} / \mathrm{L}$. Results also indicated that the optimum temperature for maximum lipid content by C. curvatus PY 39 was $30^{\circ} \mathrm{C}$ that led to lipid content of $45.49 \pm 0.67 \%$ (Table 3 ). On the other hand, this strain gave the least amount of biomass, lipid yield and lipid content at temperature of $40^{\circ} \mathrm{C}$. Based on this, C. curvatus PY39 gave biomass $(8.17 \pm 0.13 \mathrm{~g} / \mathrm{L})$ and lipid content 
$(23.50 \pm 0.36 \%)$. Since the maximum lipid content was observed at the temperature of $30^{\circ} \mathrm{C}$ by this oleaginous yeast, this temperature was selected for further experiments.

The effects of agitation rate on cell biomass production, lipid yield and lipid content by the $\mathrm{C}$. curvatus PY39 were determined under nitrogen-limited conditions by varying the agitation speed from 100 to $225 \mathrm{rpm}$ is depicted in Table 3. A sharp increase in biomass and lipid yield as well as lipid content was exhibited by C. curvatus PY39 when the agitation speed was increased from 100 to $225 \mathrm{rpm}$. This strain gave maximum lipid yield $(5.50 \pm 0.66 \mathrm{~g} / \mathrm{L})$ and lipid content $(40.00 \pm 2.36 \%)$ per dry biomass of $13.75 \pm$ $0.77 \mathrm{~g} / \mathrm{L}$ at the agitation speed of $225 \mathrm{rpm}$.

Results from Table 3 also indicate that the agitation speed that led to the lowest biomass and lipid content was $100 \mathrm{rpm}$ for $\mathrm{C}$. curvatus PY39 leading to biomass production, lipid yield and lipid contents of $11.44 \pm 0.41 \mathrm{~g} / \mathrm{L}$ and $2.96 \pm 0.25 \mathrm{~g} / \mathrm{L}$, respectively. Based on the facts generated, all further experiments were carried out in nitrogen-limited media at agitation speed of $225 \mathrm{rpm}$ for C. curvatus PY39.

Biomass production, lipid yield and cellular lipid content of C.curvatus PY39, were tested at $0,24,48,72,96$, 120,144 and $168 \mathrm{~h}$ in nitrogen-limited media separately. It was apparent that, there was a sharp increase in biomass production, lipid yield and lipid content from 0 to $144 \mathrm{~h}$ by $\mathrm{C}$. curvatus PY39. Maximum lipid yield of $7.22 \pm 0.26 \mathrm{~g} / \mathrm{L}$ was attained by C. curvatus PY39 which corresponds to a lipid content of $46.01 \pm$ $0.50 \%$ per biomass of $15.69 \pm 0.86 \mathrm{~g} / \mathrm{L}$ at $144 \mathrm{~h}$ incubation (Table 3 ).

\section{Estimation of total sugar in peel mixtures of papaya and mango}

Total sugar present in fruit peel mixture was estimated at absorbance of $490 \mathrm{~nm}$ with different concentration of working standard of glucose solution depicted in Fig. 2. Percentage of total sugar in the fruit peel sample mixture was $13.20 \%$.

\section{Production of single cell oil using peel mixtures of papaya and mango}

Biomass, lipid yield and cellular lipid content of C.curvatus PY39 was tested by growing them on peel mixture of papaya and mango hydrolysate that were inoculated $10 \% \mathrm{v} / \mathrm{v}\left(\sim 7.94 \times 10^{8} \mathrm{cells} / \mathrm{mL}\right)$ seed cultures. The results obtained in this study were considerable and showed high potential of biomass, lipid yield and lipid content by the investigated C.curvatus PY39. C.curvatus PY39 when grown on peel mixtures gave biomass, lipid yield and lipid content of $11.28 \pm 0.61 \mathrm{~g} / \mathrm{L}, 3.95 \pm 0.67 \mathrm{~g} / \mathrm{L}$ and $35.02 \pm$ $1.63 \%$, respectively.

\section{Discussion}


Biomass production, lipid accumulation and fatty acid profile of oleaginous microorganisms are affected by the carbon source available during fermentation $[5,25]$. For the production of maximum cell biomass and lipid in oleaginous yeasts, medium with an excess of carbon source and limited amount of nitrogen sources has a significant influence [26]. In this study, glucose, sucrose, maltose, galactose, xylose and glycerol were tested as carbon sources for the production of cell biomass and cellular lipid content. As it can be seen in Table 1, glucose as a carbon source gave maximum biomass and cellular lipid content by C. curvatus PY39. Considerable biomasses and lipid contents were also attained by this strain when grown both on sucrose and maltose. Ratledge [27], Saxena [28], Zhao et al. [29], Ahmad et al. [30] and Enshaeieh et al. [31] also reported glucose as the best carbon source for production of SCO.

On the other hand, lowest biomass and cellular lipid content were exhibited by this strain when xylose was used as a carbon source (Table 1). For economic reasons however glucose is not recommended for industrial production of SCO. Even though this oleaginous yeast gave lowest biomass and lipid content when xylose was supplied as a carbon source, it is still recommended for industrial production of SCO because it is obtained from cheap cellulosic wastes.

To evaluate the performance of different carbon substrates including wastes, glucose is often used as a comparison basis. Therefore, in this study we investigated the effect of glucose concentration, ranging from 10 to $90 \mathrm{~g} / \mathrm{L}$, for biomass and SCO yields by C. curvatus PY39. From the evaluated glucose concentrations, higher lipid production was exhibited by C. curvatus PY39 when this oleaginous yeast was grown in nitrogen-limited media containing $70 \mathrm{~g} / \mathrm{L}$ of glucose (Table 1). When the tested yeast grew on media containing lower concentrations of glucose (especially $10 \mathrm{~g} / \mathrm{L}$ and $30 \mathrm{~g} / \mathrm{L}$ glucose), it yielded considerable biomass and lipid. Thus, it is recommended that such lower glucose concentrations should be used for industrial production of SCO. This saves cost of production. Previous researchers also reported different glucose concentrations for maximum production of biomass, lipid concentration and lipid content by various oleaginous yeasts. Accordingly, Enshaeieh et al. [32] reported $75 \mathrm{~g} / \mathrm{L}$ for maximum production of biomass $(12.7 \mathrm{~g} / \mathrm{L})$, lipid yield $(7.13 \mathrm{~g} / \mathrm{L})$ and lipid content by Rhodotorula sp.110, while Kraisintu et al.[33] reported $70 \mathrm{~g} / \mathrm{L}$ as the optimum glucose concentration for Rhodosporidium toruloides DMKU3-TK16 for maximum production of biomass, lipid yield and lipid content. Media containing concentrations of 80 and $90 \mathrm{~g} / \mathrm{L}$ glucose were the best for maximum production of biomass, lipid yield and lipid content by Torulaspora globosa YU5/2 [34] and Rhodotorula mucilaginosa $F[35]$, respectively.

In this study, the effect of combined organic and inorganic nitrogen sources on biomass production, lipid yield and cellular lipid content by C. curvatus PY39 was determined in nitrogen-limited media. The results showed that combinations of $\left(\mathrm{NH}_{4}\right)_{2} \mathrm{SO}_{4}$ and yeast extract were the most favorable nitrogen sources for the maximum lipid production by C. curvatus PY39 among the different combinations tested as nitrogen compounds (Table 1). However, this yeast gave lowest biomass and cellular lipid content when it was grown in a media containing $\mathrm{NH}_{4} \mathrm{Cl}$ and urea as nitrogen sources. These differences may be due to the assimilation preferences of some nitrogen sources over the others [36]. According to previous researchers, different nitrogen sources supported different oleaginous yeasts either in combination or 
alone. Trichosporon fermentans gave maximum biomass and lipid content when it was grown in media containing urea and peptone, respectively [37]. On the other hand, Kraisintu et al.[33] reported that Rhodosporidium toruloides DMKU3-TK16 gave the highest biomass when the yeast was grown in a medium containing yeast extract and $\left(\mathrm{NH}_{4}\right)_{2} \mathrm{SO}_{4}$ as nitrogen sources, while higher cellular lipid contents of 53.71 and $53.10 \%$ were produced, when peptone was provided with $\mathrm{NH}_{4} \mathrm{Cl}$ and with $\left(\mathrm{NH}_{4}\right)_{2} \mathrm{SO}_{4}$,respectivley. Maximum biomass $(17.57 \mathrm{~g} / \mathrm{L})$, lipid yield $(6.29 \mathrm{~g} / \mathrm{L})$ and lipid content $(35.78 \%)$ were exhibited by Rhodotorula sp. 110 when yeast extract and $\left(\mathrm{NH}_{4}\right)_{2} \mathrm{SO}_{4}$ were used in combination [32].

For the production of lipid by oleaginous microorganisms, there must be nutrient imbalance culture medium and specifically the $\mathrm{C} / \mathrm{N}$ ratio has to be high $[4,38,39]$. In the current study, the selected oleaginous yeasts exhibited maximum biomass, lipid yield and lipid content at the $\mathrm{C} / \mathrm{N}$ ratio of 140 (Table 1). Such optimum $\mathrm{C} / \mathrm{N}$ ratio that enables $\mathrm{C}$. curvatus $\mathrm{PY} 39$ to accumulate maximum lipid was found to be high. This means that, in a high $\mathrm{C} / \mathrm{N}$ ratio medium, the depletion of the nitrogen levels is rapid and that sugar would selectively go in for lipid synthesis, thereby accounting for high lipid yield [40, 41]. Other researchers also reported $\mathrm{C} / \mathrm{N}$ ratio as an important parameter for maximum lipid production and found optimum C/N ratios for the yeasts they tested and hence 77, 163 and 140 were found to be the optimum $\mathrm{C} / \mathrm{N}$ ratios for maximum biomass and lipid production by Rhodosporidium toruloides ATCC 10788[42], Trichosporon fermentans [37] and Rhodosporidium toruloides DMAKU3-TK16 [33], respectively.

$\mathrm{pH}$ is one of the most important physiological factors affecting cell growth and lipid production[43]. In this study, highest biomasses were obtained when the $\mathrm{pH}$ media were kept at 5.0 and 5.5, while maximum lipid yield and lipid content were attained by C. curvatus PY39 when the $\mathrm{pH}$ values of 5.0 and 5.5 (Table 3), indicating that the tested oleaginous yeast prefer acidic $\mathrm{pH}$ to grow and accumulate lipids $[4,5,44]$. Previous studies also reported similar $\mathrm{pH}$ values for different oleaginous yeasts. Accordingly, 5.0 was the optimum and selected pH for Lipomyces starkeyi [45] and Rhodotorula glutinis EF081370 [46] for maximum production of biomass and lipid, while 5.5 was the best $\mathrm{pH}$ for Rhodosporidium toruloides DMKU3-TK16 [33], Cryptococcus curvatus NRRLY - 1511 (El-[11] for maximum production of biomass and lipid. $\mathrm{pH}$ of 6.0 was the optimum value for maximum production of biomass and lipid yield by Trichosporon fermentans [47] and Trichosporon cutaneum [48].

Cellular lipid accumulation is critically affected by the culture temperature. Temperature affects all living organisms and controls the growth rate, lipid synthesis and alters the composition of fatty acids at cellular level $[5,25]$. In the current study, C. curvatus PY39 exhibited maximum biomasses at temperatures of 20,25 and $30^{\circ} \mathrm{C}$, the biomasses exhibited at these temperatures were significantly the same. Maximum lipid content was attained by C. curvatus PY39 at the growth temperature of $30^{\circ} \mathrm{C}$. Such results show that temperature of lipid synthesis and cell growth temperature are not consistent [5]. Maximum lipid content obtained at $30^{\circ} \mathrm{C}$ was in line with the results reported by Hong et al. [43], Syed et al. [49] and Mamatha [25]. It was evident in this research work that at a temperature of $40^{\circ} \mathrm{C}$, the least biomass, lipid yield and lipid content were exhibited by this strain. An increase in temperature will 
increase enzyme activity. If the temperature is too high, enzyme activity will diminish (enzymes may be denatured). Lowering temperature will decrease enzyme activity. Such effects in turn might influence on biomass production and lipid yield.

Agitation and aeration have great importance in aerobic culture to increase biomass and hence lipid production [50]. In the current study, the optimum agitation speed for maximum biomass production and lipid content by C. curvatus PY39 was at $225 \mathrm{rpm}$. This is because the higher the agitation speed, the oxygen that dissolve in the medium become higher and it increases growth and lipid content as energy metabolism and synthesis of lipid components need oxygen [6]. Too low shaking speed of the flask culture would cause low dissolved oxygen in the medium, limits cell growth and synthesis of oil, whereas too high rotation speed could cause the shear stress to become larger and reduces cell growth and synthesis of oil [5]. Other researchers also investigated optimum agitation speeds for different oleaginous yeasts. Accordingly, 180 and $200 \mathrm{rpm}$ were optimum agitation speeds for Rhodotorula glutinis [51] and C. curvatus NRRLY - 1511 [11], respectively.

Different oleaginous microorganisms require different culture time (incubation period) for maximum biomass production and lipid accumulation [11, 33, 43, 51]. In the current study, C. curvatus PY39 exhibited highest biomass and lipid content towards the latter incubation periods ( $144 \mathrm{~h}$ ). In the previous studies, researchers have found that there is a close relationship between the length of incubation period and the best time for the synthesis of lipids [5]. There were reports of oleaginous yeasts during the whole growth period, the accumulation of oil was very little in the early stage because of the nutrients and cell growth, most oil (grease) was used to the synthesis of cell membrane, the lipid would have increased significantly and reach the peak in the stable phase [5]. Other researchers also reported different optimum incubation periods for maximum production of lipid by different oleaginous yeasts. Incubation period of $72 \mathrm{~h}$ was optimum for maximum biomass and lipid production both in R.glutinis [51] and C.curvatus NRRLY - 1511 [11]. On the other hand, Rhodosporidium toruloides DMKU3-TK16 exhibited maximal lipid yield and lipid cellular lipid content after $168 \mathrm{~h}$ of cultivation [33].

Fruit based industries produce large volume of wastes, these wastes pose increasing disposal and pollution problems and represent a loss of valuable biomass and nutrients [52]. However, these carbohydrate rich wastes can be tuned into valuable substrates for the commercial production of lipids and thus can be regarded as available option for meeting the growing demand for lipids. For economic reasons, low-cost feedstock substrates such as peels of orange, banana, potato, sugarcane bagasse, corn stalk, tomato waste, rice bran, rice straw and rice hull was used as a carbon source for the production of SCO $[8,7,35,53]$. On the other hand, such fruit wastes have limitations such as their seasonal availability, substrate preparation cost, high water content and spoilage problems. Still with limitations they can be alternative feedstocks.

Microbial lipids have long been considered as an alternative to sources of conventional oils. To produce such lipids, oleaginous microorganisms, especially oleaginous yeasts have to be grown on cheap substrates for economic reasons. Taking this into account, C. curvatus PY39 was cultivated under 
nitrogen-limited media containing papaya and mango peel mixtures for the production of lipid. Peel mixture of papaya and mango hydrolysate were found to be rich in carbohydrate content and supported the growth of $\mathrm{C}$. curvatus PY39. The results obtained in this study are in agreement with the research works by Tinoi and Rakariyatham [54] on utilization of pineapple waste hydrolysate for lipid production by Rhodoturula glutinis and Rattanapoltee and Kaewkannetra [55] on hetrotrophic growth of a microalga, namely Scenedesmus acutus that cultivated on pineapple peels.

The type of species and growth conditions such as temperature, $\mathrm{pH}$, type of substrate (medium of composition), variation in $\mathrm{C} / \mathrm{N}$ ratio, and oxygen availability influence the fatty acid profiles and the efficiency of lipid accumulation [56, 57]. In this study, the fatty acid profiles of C.curvatus PY39, was evaluated using GC. It was observed that the fatty acid compositions are qualitatively similar but slightly differ quantitatively.

C.curvatus PY39 exhibited a predominant amount of oleic acid and low amounts of other fatty acids (linoleic acid, palmitic acid, linolenic acid, palmitoleic acid, paulinic acid, arachidic acid and behenic acid). The fatty acid profile determined in the current study displayed preferential synthesis of high percentage of saturated and monounsaturated fatty acids in the C.curvatus PY39. The concentration of saturated and monounsaturated fatty acids of C.curvatus PY39 added up $85.24 \pm 2.63 \%$. In previous studies, researchers have also reported oleic acid as the major fatty acid in SCOs followed by palmitic acid and low amount of other fatty acids $[30,58,59]$. The fatty acids that were exhibited by the four strains were not only similar to fatty acid profiles of other oleaginous yeasts but also they fit well with the fatty acid profiles of different vegetable oils such as rapeseed, soybean, palm, and sunflower [60, 61]. From these comparisons, one can see that there are similarities with the relative abundance of fatty acid profiles with slight differences. This again confirmed that the lipids from these oleaginous yeasts are good oil feedstock for biodiesel production. In addition, the main components of fatty acid profiles of the four oleaginous yeasts are C16:0, C18:0, C18:1 and C18:2 which is similar to cacao-butter [62]. Thus, such fatty acids can be used for human consumption.

\section{Conclusion}

Culture conditions played a critical role on the growth rate and lipid accumulation by C. curvatus PY39. Comparing the results with previous data, it is clear that there are some differences across species and strains and it is, therefore, important to investigate the optimal parameters for each strain tested. This study also showed the capacity of C. curvatus PY39 to utilize peel mixtures of papaya and mango hydolysate as a media for the production of biomass and lipid. Thus, peel mixtures of papaya and mango hydolysate could be used as cheap substrates for the cost-effective production of SCO which is used as a feedstock for the preparation of biodiesel. The ability to utilize fruit peel hydrolysate is very important from an environmental point of view. This research work provides an insight to cultivate oleaginous yeasts on other lignocellulosic wastes. C. curvatus PY39 have been observed to realize its ability to produce higher concentrations of saturated and monounsaturated fatty acids (with oleic acid 
the most dominant) than those of unsaturated fatty acids. This makes this oleaginous yeast the most promising candidates for biodiesel production.

\section{Methods}

\section{Yeast strain}

In this study, 200 samples were collected from soil, plant surfaces (leaves, flowers and fruits), traditional oil mill wastes, and dairy products (cheese, milk and yoghurt) in Ethiopia. Yeast isolation was performed according to the methods of Pan et al. [24]. Three hundred and forty yeast colonies were isolated from these samples. It was found that the yeast strain PY39, which was isolated from flower contained oil content of $46.51 \pm 0.70 \% \mathrm{w} / \mathrm{w}$. This strain was identified as C.curvatus, using both conventional (morphological and physiological) and molecular (sequencing both ITS domains and D1/D2 domains of the large subunit) by Jiru et al. [63].The accession number for this strain is KX525704.

\section{Inoculum Preparation}

A loopful of yeast cells from growing on Yeast Malt (YM) extract agar slants, containing glucose $(10 \mathrm{~g} / \mathrm{L})$, peptone $(5 \mathrm{~g} / \mathrm{L})$,yeast extract $(3 \mathrm{~g} / \mathrm{L})$, malt extract $(3 \mathrm{~g} / \mathrm{L})$ and agar $(20 \mathrm{~g} / \mathrm{L})$, were inoculated into a sterilized nitrogen-limited medium containing, glucose $(50 \mathrm{~g} / \mathrm{L}),\left(\mathrm{NH}_{4}\right)_{2} \mathrm{SO}_{4}(0.31 \mathrm{~g} / \mathrm{L})$, yeast extract $(0.50 \mathrm{~g} / \mathrm{L}), \mathrm{MgSO}_{4} .7 \mathrm{H}_{2} \mathrm{O}(1.5 \mathrm{~g} / \mathrm{L}), \mathrm{CaCl}_{2} .2 \mathrm{H}_{2} \mathrm{O}(0.1 \mathrm{~g} / \mathrm{L}), \mathrm{KH}_{2} \mathrm{PO}_{4}(1.0 \mathrm{~g} / \mathrm{L}), \mathrm{FeSO}_{4} .7 \mathrm{H}_{2} \mathrm{O}(0.035 \mathrm{~g} / \mathrm{L})$, $\mathrm{ZnSO}_{4} \cdot 7 \mathrm{H}_{2} \mathrm{O}(0.011 \mathrm{~g} / \mathrm{L}), \mathrm{MnSO}_{4} \cdot \mathrm{H}_{2} \mathrm{O}(0.007 \mathrm{~g} / \mathrm{L}), \mathrm{CoCl} 6 \mathrm{H}_{2} \mathrm{O}(0.002 \mathrm{~g} / \mathrm{L}), \mathrm{Na}_{2} \mathrm{MoO}_{4} \cdot 2 \mathrm{H}_{2} \mathrm{O}(0.0013 \mathrm{~g} / \mathrm{L})$ and $\mathrm{CuSO}_{4} \cdot 5 \mathrm{H}_{2} \mathrm{O}(0.001 \mathrm{~g} / \mathrm{L})$. The culture was allowed to grow for $24 \mathrm{~h}$ at $30^{\circ} \mathrm{C}$, pH 5.5 at $200 \mathrm{rpm}$. An inoculum of $10 \% \mathrm{v} / \mathrm{v}\left(\sim 7.94 \times 10^{8}\right.$ cells $\left./ \mathrm{mL}\right)$ was added to the nitrogen-limited cultivation medium.

Optimization of culture conditions for biomass production and lipid accumulation

The influence of carbon sources (glucose, sucrose, maltose, galactose, xylose and glycerol), glucose concentration $(10,30,50,70$ and $90 \mathrm{~g} / \mathrm{L})$, nitrogen sources $\left[\mathrm{NH}_{4}\right)_{2} \mathrm{SO}_{4}$ and yeast extract, $\mathrm{NH}_{4} \mathrm{Cl}$ and peptone, $\mathrm{NH}_{4} \mathrm{Cl}$ and yeast extract, $\left(\mathrm{NH}_{4}\right)_{2} \mathrm{SO}_{4}$ and peptone, $\left(\mathrm{NH}_{4}\right)_{2} \mathrm{SO}_{4}$ and urea, $\mathrm{NH}_{4} \mathrm{Cl}$ and urea], $\mathrm{C} / \mathrm{N}$ ratio $(40,60,80,100,120,140$ and 160$), \mathrm{pH}(4.0,4.5,5.0,5.5,6.0,6.5$ and 7.0$)$, temperature $\left(20^{\circ} \mathrm{C}, 2^{\circ} \mathrm{C}\right.$, $30^{\circ} \mathrm{C}, 35^{\circ} \mathrm{C}$ and $\left.40^{\circ} \mathrm{C}\right)$, agitation speed $(100,125,150,175,200$ and $225 \mathrm{rpm})$ and incubation period $(0,24$, $48,72,96,120,144$ and $168 \mathrm{~h}$ ) were tested in a nitrogen-limited media. One parameter was tested at a time. Dry biomass, lipid yield and lipid content were determined. Cultures were grown in $250 \mathrm{~mL}$ Erlenmeyer flasks containing $50 \mathrm{~mL}$ media. For determination of $\mathrm{C} / \mathrm{N}$ ratio, total nitrogen content of yeast extract was determined using Kjeldahl apparatus according to the instructions published by Krishna and Ranjhan [64].

\section{Dry Cell Weight Determination}


In series of the propagation processes, cell harvest and biomass determination was done according to Pan et al. [24]. Cells were harvested by centrifugation at $5000 \times \mathrm{g}$ for $15 \mathrm{~min}$, washed twice with distilled water, frozen at $-80^{\circ} \mathrm{C}$ and freeze dried overnight to constant weight. The dry biomass was determined gravimetrically.

\section{Determination Of Lipid Content}

Lipid extraction was done following the method described by Folch et al. [65], with some modifications. Freeze dried biomass was ground with a pestle in a mortar and $1 \mathrm{~g}$ of sample was extracted with $3.75 \mathrm{~mL}$ solvent mixture of chloroform and methanol (2:1) overnight. The solvent mixture was transferred into a clean separating funnel through Whatman No1 filter paper. Then $1.25 \mathrm{~mL}$ of the solvent mixture was added through filter paper into separating funnel. This was followed by washing with $0.75 \mathrm{~mL}$ of distilled water. The solvent/water mixture was left overnight to separate into two clear phases. The bottom phase was collected and the solvents evaporated under vacuum. Diethyl ether was used to transfer the extract into pre-weighed glass vials and the solvent evaporated. The dry lipids were weighed and lipid content calculated.

Single cell oil content $=\frac{\text { Single Cell Oil Weight }(\mathrm{g} / \mathrm{L})}{\text { Cell Dry Weight }(\mathrm{g} / \mathrm{L})} \times 100$

\section{Production of single cell oil using peel mixture of papaya and mango}

\section{Substrate Collection And Preparation}

Fresh papaya and mango peels were collected from fruit processors within the Arat Kilo area, Addis Ababa, Ethiopia. The peels were thoroughly washed with water to remove attached foreign materials. Then the peel mixture was homogenized and blended for $5 \mathrm{~min}$. A $2 \%(\mathrm{v} / \mathrm{v})$ sulphuric acid at a solid to liquid ratio of $1: 10(\mathrm{w} / \mathrm{v})$ was added in to the fruit peel mixture for hydrolysis. A $2 \mathrm{~mm}$ screen was used to sieve the resulting slurry before being stored at $20^{\circ} \mathrm{C}$ for subsequent use. The diluted peel mixture then was boiled, allowed to cool and sedimentation of insoluble materials occurred. The sediments were removed by decantation. The resulting mixture was centrifuged with a high speed at $5000 \times g$ for $10 \mathrm{~min}$ for further removal of insoluble materials. The supernatant solution was separated from the pellet. The pellet was discarded and the supernatant was used for the cultivation purpose.

\section{Determination of total sugar in papaya and mango peel mixtures}


Sample preparation: For determination of total sugar, $100 \mathrm{mg}$ of peel mixture of papaya and mango was homogenized and taken in boiling tube and hydrolyzed by adding $5 \mathrm{~mL}$ of $96 \%$ sulphuric acid in it. Boiling tubes were kept in water bath for $3 \mathrm{~h}$ and then removed from water bath and cooled to room temperature. After cooling, it was neutralized by adding solid sodium carbonate until effervescence ceases. Then whole volume was made up to $100 \mathrm{~mL}$ by adding distilled water and centrifuged. Then the supernatant was used for total sugar estimation.

Total sugar estimation: Total sugar contained in fruit peel mixture was analyzed by the method of DuBois et al. [66] which is based on the phenol - sulphuric acid reaction. The standard curve for glucose was prepared by adjusting the final concentration to $0.2 \mathrm{mg} / \mathrm{mL}$ as $0,0.02,0.04,0.06,0.08,0.1,0.12,0.14$, $0.16,0.18$, and 0.2 . The final volume of each tube was made $2 \mathrm{~mL}$ by adding distilled water. The amount of fruit peel sample used was $0.2 \mathrm{~mL}$. One $\mathrm{mL}$ of $5 \%$ phenol and $5 \mathrm{~mL}$ of $96 \%$ sulphuric acid was added one by one in each tube and vortexed well so that the phenol and sulphuric acid get mixed thoroughly with working standard. After $10 \mathrm{~min}$ all the tubes were placed in water bath at $25^{\circ} \mathrm{C}$ for $15 \mathrm{~min}$. At last the absorbance was read at $490 \mathrm{~nm}$ using spectrophotometer (JENWAY model 6405). The total sugar in the fruit peel mixture was calculated following the protocols developed by Sadasivam and Manickam [67].

Absorbance corresponds to $0.2 \mathrm{~mL}$ of fruit peel sample test $=\mathrm{x}$ mg of glucose

$100 \mathrm{~mL}$ of peel sample solution contain $=\frac{\mathrm{x}}{0.2} \times 100=\%$ of total sugar present

\section{Production of single cell oil from oleaginous yeasts peel wastes}

Production of SCO was tested in a nitrogen-limited media as listed in the previous chapters except the carbon source. In this case the carbon source used was fruit peel mixture and the amount used was estimated according to the method of DuBois et al. [66] and Sadasivam and Manickam [67]. Fruit peel mixture of $53 \%(\sim 70 \mathrm{~g} / \mathrm{L})$ was used. The fermentation medium was inoculated with $10 \%(\mathrm{v} / \mathrm{v})$ of the liquid seed culture.

All the optimized parameters were applied here for the production of SCO by each of this oleaginous yeast using peel mixtures of papaya and mango.

\section{Analysis of fatty acids profiles using gas chromatography}

To determine the fatty acid composition of the lipids, the extracted lipids were transferred to GC vials, dissolved in chloroform and methylated with trimethylsulphonium hydroxide (TMSOH) [68]. The vials were then sealed and vortexed for approximately $5 \mathrm{sec}$. Fatty acid methyl esters were subsequently analyzed on a Shimadzu GC-2010 gas chromatograph with a flame ionization detector. An injection volume of $0.5 \mu \mathrm{L}$ of sample was added into a SGE-BPX-70 column (length of $50 \mathrm{~m}$ and inner diameter 
$0.22 \mathrm{~mm}$ ). The injection port had a temperature of $250^{\circ} \mathrm{C}$ and a split ratio of $1: 10$. The column temperature was $200^{\circ} \mathrm{C}$. Hydrogen gas was used as a carrier gas at a flow rate of $40 \mathrm{~mL} / \mathrm{min}$. The total program time was $4.50 \mathrm{~min}$ per sample with a column flow rate of $1.37 \mathrm{~mL} / \mathrm{min}$. Peaks were identified by reference to authentic standards.

\section{Statistical analysis}

All experiments were done in triplicate. One way-ANOVA was performed to calculate significant differences in treatment means. SPSS version 20.0 software was used for interpretation of the data. Mean separations were performed by Tukey post hoc tests. A $p$ value $<0.05$ was considered significant.

\section{Abbreviations}

SCO: Single Cell Oil; GC: Gas Chromatography; TAGs: Triacylglycerols

\section{Declarations}

\section{Acknowledgements}

The author would like to acknowledge Marizeth Groenewald (PhD), Carolina Pohl (PhD), Dawit Abate $(\mathrm{PhD})$ and Nicholas Kiggundu $(\mathrm{PhD})$ for their help during the research work. The author is thankful to Ethiopian Ministry of Science and Technology for their financial support.

\section{Authors' contributions}

TM performed the experiments as part of his doctoral work.

\section{Funding}

This work was supported by the Ethiopian Ministry of Science and Technology.

\section{Availability of data and materials}

The sequence dataset generated for this isolate is available in the NCBI Short Read Archive repository (Accession Number KX525704).

\section{Ethics approval and consent to participate}

Not applicable.

\section{Consent for publication}

Not applicable. 


\section{Competing interest}

Not applicable.

\section{Author details}

Department of Environmental and Industrial Biotechnology, Institute of Biotechnology, University of Gondar, Email Address: tamene1971@gmailcom, P.O.Box:196, Gondar, Ethiopia.

\section{References}

1. Ratledge C, Wynn JP.The biochemistry and molecular biology of lipid accumulation in oleaginous microorganisms. Adv Appl Microbiol.2002; 51: 1-51.

2. Li Q, Du W, Liu D. Perspectives of microbial oils for biodiesel production. Appl Microbiol Biotechnol.2008; 80:749-756.

3. Luque R, Lovett JC, Datta B, Clancy J, Campelo JM, Romero AA. Biodiesel as feasible petrol fuel replacement: a multidisciplinary overview. Energ Enivron Sci. 2010; 3:1706- 1721.

4. Ageitos JM, Vallejo JA, Veiga-Crespo P, Villa TG.Oily yeasts as oleaginous cell factories. Appl. Microbiol Biotechnol.2011; 90:1219-1227.

5. Zhao C, Liu ZG, Qingli Z, Sun G, Tang X, Shi W, Lu X. Effects of culture conditions on single cell oil accumulation. J Chem Pharm Res.2015; 7:2189-2191.

6. Enshaeieh M, Abdoli A, Nahvi I. Medium optimization for biotechnological production of single cell oil using Yarrowia lipolytica M7 and Candida J Cell Mol Res.2013b; 5:17-23.

7. Economou CN, Aggelis G, HYPERLINK "http://www.sciencedirect.com/science/article/pii/S0960852411011138"Pavlou S, Vayenas DV. Single cell oil production from rice hulls hydrolysate. Bioresour Technol. 2011; 102: 9737-9742.

8. Huang $\mathrm{C}$, Zong M, Wu H, Liu Q. Microbial oil production from rice straw hydrolysate by Trichosporon fermentans. Bioresour Technol.2009; 100: 4535-4538.

9. Sriwongchai S, Pokethitiyook P, Kruatrachue M, Bajwa PK, Lee H. Screening of selected oleaginous yeasts for lipid production from glycerol and some factors which affect lipid production by Yarrowia lipolytica J Microbiol Biotechnol Food Sci.2013; 2: 2344-2348.

10. Moustogianni A, Bellou S, Triantaphyllidou IE, Aggelis G. Feasibility of raw glycerol conversion into single cell oil by zygomycetes under non-aseptic conditions. Biotechnol Bioeng. 2015; 112:827-831.

11. El-Fadaly HA, El-Naggar NA, Marwan SM. Single cell oil production by an oleaginous yeast strain in a low cultivation medium. Resear J Microbiol.2009; 4:301-313.

12. Karatay SE, Donmez G. Improving the lipid accumulation properties of the yeast cells for biodiesel production using molasses. Bioresour Technol. 2010; 101:7988-7990.

13. Gajdoš P, Nicaud JM, Rossigno T, Čertík M. Single cell oil production on molasses by Yarrowia lipolytica strains overexpressing DGA2 in multicopy. Appl Microbiol Biotechnol.2015; 99:8065-8074. 
14. Cheirsilp B, Suwannarat W, Niyomdecha R. Mixed culture of oleaginous yeast Rhodotorula glutinis and microalga Chlorella vulgaris for lipid production. New Biotechnol.2011; 28:362-368.

15. Akhtar P, Gray I, Asghar A. Synthesis of lipids by certain yeast strains grown on whey permeate. J Food Lipids.1998; 5:283-297.

16. Lutzu GA, Zhang W, Liu T. Feasibility of using brewery wastewater for biodiesel production and nutrient removal by Scenedesmus dimorphus. Environ Technol.2016; 37:1568-1581.

17. Xue F, Gao B, Zhu Y, Zhang X, Feng W, Tan T. Pilot-scale production of microbial lipid using starch wastewater as raw material. Bioresour Technol.2010; 101: 6092-6095.

18. Kulkarni A, Singh A, Kumbhar BK, Sahgal M. Optimization of pomace and banana peel fermentation for production of single cell oil. FMFI.2013; 2:170-178.

19. Park WK, Moon M, Kwak MS, Jeon S, Choi GG, Lee B. Use of orange peel extract for mixotrophic cultivation of Chlorella vulgaris: Increased production of biomass and FAMEs. Bioresour Technol. 2014; 171: 343-349.

20. Choi IS, Lee YG, Khanal SK, Park BJ, Bae HJ. A low-energy, cost-effective approach to fruit and citrus peel waste processing for bioethanol production. Appl Energ.2015; 140: 65-74.

21. Puligundla P, Obulam VSR, Oh SE, Mok C. Biotechnological potentialities and valorization of mango peel waste: A Review. Sains Malaysiana.2014; 43: 1901-1906.

22. Faturoti BO, Emah GN, Isife Bl, Tenkouano A, Lemchi J. Prospects and determinants of adoption of IITA plantain and banana based technologies in three Niger Delta States of Nigeria. African J Biotechnol. 2006; 5:1319-

23. Hassan M, Blanc CJ, Pareilleux A, Goma G. Production of single cell oil from prickly-pear juice fermentation by Cryptococcus curvatus grown in batch culture. World J Microbiol Biotechnol.1994; 10:534-537.

24. Pan LX, Yang DF, Shao L, Li W, Chen WGG, Liang ZQ. Isolation of the oleaginous yeasts from the soil and studies of their lipid producing capacities. Food Technol Biotechnol. 2009; 47: 215-220.

25. Mamatha SS. Polyunsaturated fatty acids of Mucor with special reference to gamma linolenic acid, thesis submitted to the University of Mysore for the award of degree of doctor of philosophy in microbiology, Mysore;2009.

26. Ratledge $C$. Fatty acid biosynthesis in microorganisms being used for single cell oil production. Biochemie.2004; 86:807-815.

27. Ratledge $C$. Regulation of lipid accumulation in oleaginous microorganisms. Biochem Soci Trans.2002; 6:1047-1050.

28. Saxena RK, Anand P, Saran S, Isar J. Microbial production of 1, 3-propanediol: recent developments and emerging opportunities. Biotechnol Advances.2009; 27: 895-913.

29. Zhao X, Kong X, Hua Y, Feng B Zhao ZK. Medium optimization for lipid production through cofermentation of glucose and xylose by the oleaginous yeast Lipomyces starkeyi. European J Lipid Sci Technol.2008; 110: 405-412. 
30. Ahmad FB, Zhang Z, Doherty WOS, O'Hara IM. A multi-criteria analysis approach for ranking and selection of microorganisms for the production of oils for biodiesel production. Bioresour Technol. 2015; 190: 264-273.

31. Enshaeieh M, Abdoli A, Madani M. Single cell oil (SCO) production by Rhodotorula mucilaginosa and its environmental benefits. J Agr Sci Tech.2015b; 17: 387-400.

32. Enshaeieh M, Abdoli A, Nahvi I, Madani M. Selection and optimization of single cell oil production from Rodotorula 110 using environmental waste as substrate. J Cell Mol Resear.2013a; 4: 68-75.

33. Kraisintu P, Yongmanitchai W, Limtong S. Selection and optimization for lipid production of a newly isolated oleaginous yeast, Rhodosporidium toruloides DMKU3-TK16. Kasetsart J (Nat Sci) 2010; 44:436-445.

34. Leesing R, Baojungharn R. Microbial Oil production by isolated oleaginous yeast Torulaspora globosa YU5/2. Eng Technol.2011; 76: 799-803.

35. Enshaeieh M, Abdoli A, Madani M, Bayat M. Recycling of lignocellulosic waste materials to produce high-value products: single cell oil and xylitol. Int J Environ Sci Technol.2015a; 12:837-846.

36. Evans CT, Ratledge C. Effect of nitrogen source on lipid accumulation in oleaginous yeasts. J Gen Microbiol.1984; 130: 1693-1704.

37. Zhu LY, Zong MH, Wu H. Efficient lipid production with Trichosporon fermentans and its use for biodiesel preparation. Bioresour Technol.2008; 99:7881-7885.

38. Li Y, Zhao Z, Bai F. High density cultivation of oleaginous yeast Rhodosporidium toruloides Y4 in fedbatch culture. Enzyme Microb Technol.2007; 41:312-317.

39. Beopoulos A, Chardot T, Nicaud JM. Yarrowia lipolytica: a model and a tool to understand the mechanisms implicated in lipid accumulation. Biochimie.2009; 91:692-696.

40. Moreton RS. Physiology of lipid accumulation. In: Moreton RS, editor. Single cell oil. Harlow: New York: Longmans Scientific and Technical; 1988.p. 147-165.

41. Fakas S, Papanikolaou S, Galiotou-Panayotou M, Komaitis M, Aggelis G. Organic nitrogen of tomato waste hydrolysate enhances glucose uptake and lipid accumulation in Cunninghamella echinulata. J Appl Microbiol.2008; 105: 1062-1070.

42. Turcotte IG, Kosaric Effect of $\mathrm{C} / \mathrm{N}$ ratio on lipid production by Rhodosporidium toruloides ATCC 10788. Biotechnol Lett. 1989; II: 637-642.

43. Hong LY, Bo L, Bao ZZ, Wu BF. Optimization of culture conditions for lipid production by Rhodosporidium toruloides. Chinese J Biotechnol. 2006; 4: 650-656.

44. Subramaniam R, Dufreche S, Zappi M, Bajpai R. Microbial lipids from renewable resources: production and characterization. J Ind Microbiol Biotechnol. 2010; 37:1271-1287.

45. Angerbauer $C$, Siebenhofer M, Mittelbach M, Guebitz GM. Conversion of sewage sludge into lipids by Lipomyces starkeyi for biodiesel production. Bioresour Technol. 2008; 99: 3051-3056.

46. Tao J, Dai C, Li R, Chen J, Zhang B. The changes of microdiesel composition with the culture conditions by fallen leaves of Populus euramevicana Int J Sustain Energ. 2008; 27:73-79. 
47. Wang L, Sun YM, Wang PZ, Zhao ZB. Effects of metal ions on lipid production by fermentation with Trichosporon fermentans. J Dalian Inst Light Industry. 2005; 24: 259-263.

48. Chen XF, Huang C, Yang XY, Xiong L, Chen XD, Ma LL. Evaluating the effect of medium composition and fermentation condition on the microbial oil production by Trichosporon cutaneum on corncob acid hydrolysate. Bioresour Technol.2013; 143:18-24.

49. Syed MA, Singh SK, Pandey A, Kanjilal S, Prasad RBN. Effects of various process parameters on the production of a-linolenic acid in submerged fermentation. Food Technol Biotechnol.2006; 44:282-287.

50. Saad N, Abdeshahian P, Kalil MS, Yusoff WM, Hamid AA. Optimization of aeration and agitation rate for lipid and gamma linolenic acid production by Cunninghamella bainieri 2a1 in submerged fermentation using response surface methodology. Scientific World J. 2014doi.org/10.1155/ 2014/ 280146, 1-12.

51. Dai C., Tao J, Xie F, Dai Y, Zhao M. Biodiesel generation from oleaginous yeast Rhodotorula glutinis with xylose assimilating capacity. Afri J Biotechnol. 2007; 6:2130-2134.

52. Umesh M, Preethi K. Fermentative utilization of fruit peel waste for lactic acid production by Lactobacillus plantarum. Indian JAppl Resear.2014; 4:449-

53. Shalma SM, Ranjitha J, Vijayalakshmi S. Utilization of agro waste as carbon sources for high lipid production by Aspergillus niger. Inter J Chem Tech Resear. 2016; 9:635-639.

54. Tinoi J, Rakariyatham N. Utilization of pineapple waste hydrolysate for lipid production by oleaginous yeast Rhodoturula glutinis. Int J Adv Resear. 2015; 3:1233-

55. Rattanapoltee P, Kaewkannetra P. Utilization of agricultural residues of pineapple peels and sugarcane bagasse as cost-saving raw materials in Scenedesmus acutus for lipid accumulation and biodiesel production. Appl Biochem Biotechnol.2014; 173:1495-1510.

56. Jacob Z. Yeast lipid biotechnology. Adv Appl Microbiol.1993; 39: 185-212.

57. Amaretti A, Raimondi S, Sala M, Roncaglia L, Lucia MD, Leonardi A, Rossi M. Single cell oils of the cold adapted oleaginous yeast Rhodotorula glacialis Microb Cell Fact.2010; 23: 59-73.

58. Zhao CH, Chi Z, Zhang F, Guo FJ, Li M, Song WB, Chi ZM. Direct conversion of inulin and extract of tubers of Jerusalem artichoke into single cell oil by co-cultures of Rhodotorula mucilaginosa TJY15a and immobilized inulinase-producing yeast cells. Bioresour Technol. 2011; 102: 6128-6133.

59. Seo YH, Lee IG, Han Jl. Cultivation and lipid production of yeast Cryptococcus curvatus using pretreated waste active sludge supernatant. Bioresour Technol. 2013; 135: 304-308.

60. Ma F, Hanna MA. Biodiesel production: a review. Bioresour Technol.1999; 70:1-15.

61. Christophe G, Kumar V, Nouaille R, Gaudet G, Fontanille P, Pandey A, Larroche C. Recent developments in microbial oils production: a possible alternative to vegetable oils for biodiesel without competition with human food? Braz Arch Biol Technol. 2012; 55:29-

62. Schulze I, Hansen S, Syldatk C, Neumann A. Characterization of newly isolated oleaginous yeasts Cryptococcus podzolicus, Trichosporon porosum and Pichia segobiensis. AMB Exp.2014; 4: 24. 
63. Jiru TM, Abate D, Kiggundu N, Pohl C, Groenewald M. Oleaginous yeasts from Ethiopia. AMB Exp.2016; 6:78.

64. Krishna G, Ranjhan SK. Laboratory manual for nutrition research. Vicas Publishing House Noida, Uttar Pradesh; 1980.

65. Folch J, Lees M, Sloane-Stanley GH. A simple method for the isolation and purification of total lipids from animal tissues. J Biol Chem.1957; 226:497-509.

66. DuBois M, Gilles KA, Hamilton JK, Rebers PA, Smith F. Colorimetric method for determination of sugars and related substances. Anal Chem. 1956; 28: $350-356$.

67. Sadasivam S, Manickam A. Biochemical Methods. $3^{\text {nd }}$ ed, New Age International (P) Ltd, New Delhi; 2009.

68. Butte W. Rapid method for the determination of fatty acid profiles from fats and oils using trimethylsulphonium hydroxide for transesterification. J Chromatogr. 1983; 261: 142-145.

\section{Figures}
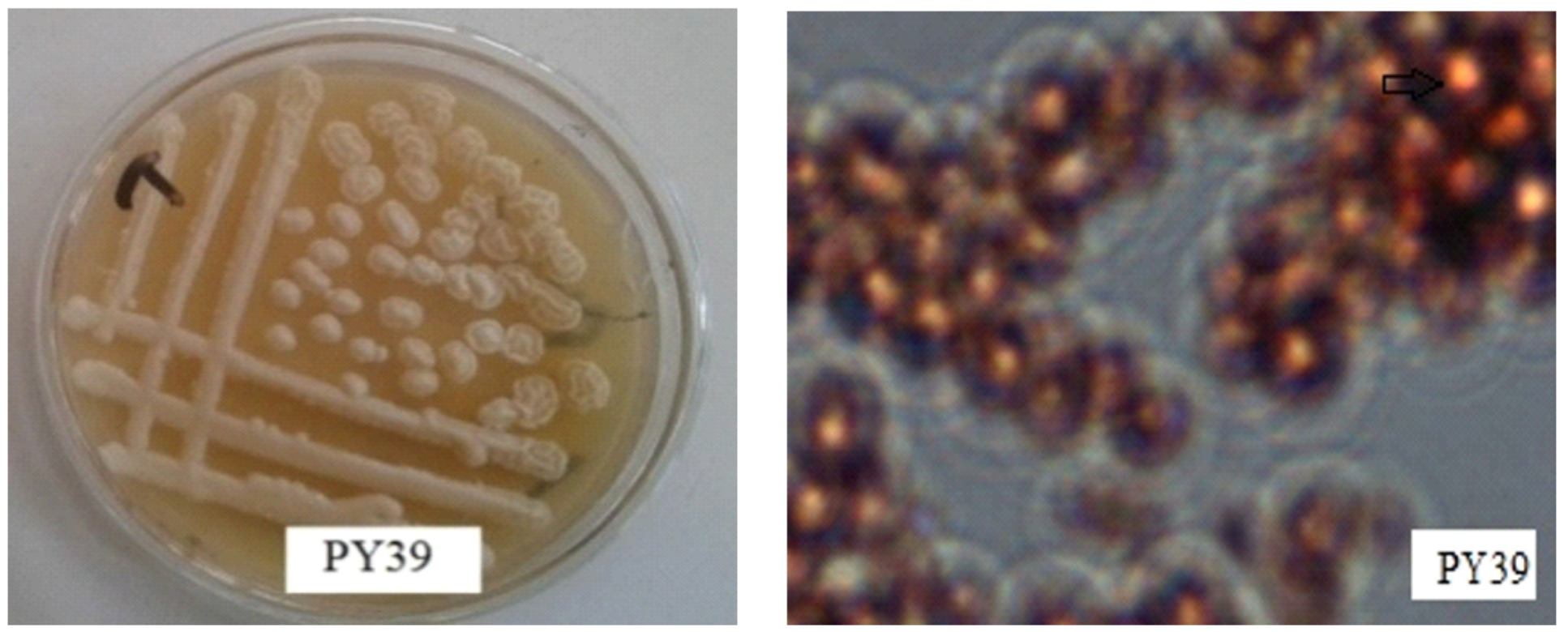

\section{Figure 1}

a) Colony morphology of PY39 and b) Sudan III stained cells of PY39. 


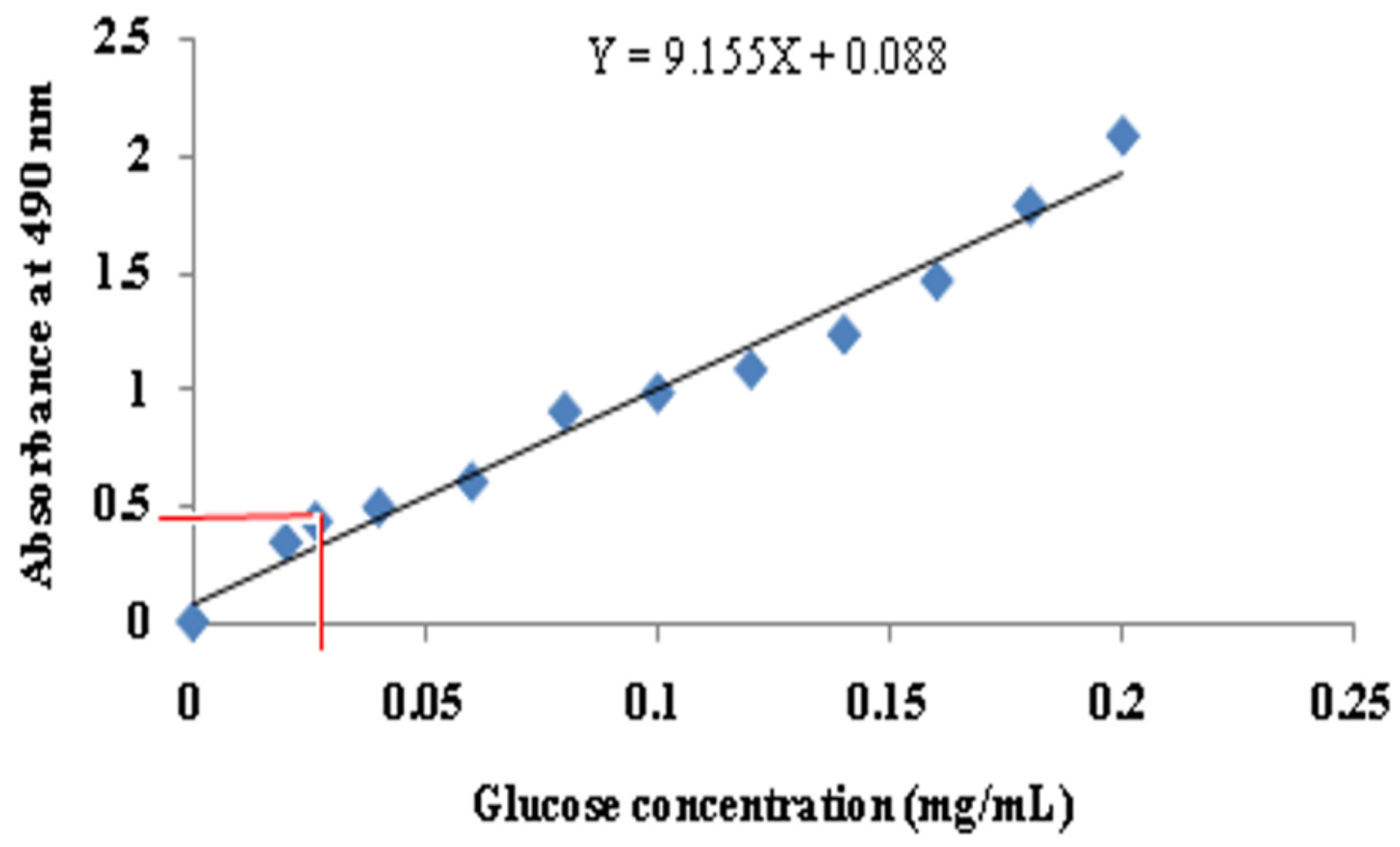

Figure 2

Standard curve of glucose for the determination of total sugar in peel mixtures of papaya and mango. 